\title{
Correction to: Inverse association between glucose-lowering medications and severe hyponatremia: a Swedish population-based case-control study
}

\author{
Henrik Falhammar $\mathbb{D}^{1,2} \cdot$ Jakob Skov $^{1} \cdot$ Jan Calissendorff ${ }^{1,2} \cdot$ Jonatan D. Lindh $^{3} \cdot$ Buster Mannheimer $^{4}$
}

Published online: 16 November 2020

(c) Springer Science+Business Media, LLC, part of Springer Nature 2020

Correction to: Endocrine

https://doi.org/10.1007/s12020-019-02160-z

The original version of this article unfortunately discovered two errors in the dataset. Instead of only including patients with a primary diagnosis of hyponatremia some cases with hyponatremia as a secondary diagnosis had been included. When corrected, the number of cases admitted with a primary diagnosis of hyponatremia were 11,213 instead of 14,359 as reported in the article, and thus the number of matched controls were 44,801 instead of 57,382 . The second error relates to the index date which is in fact the discharge date, not the admission date as initially thought.

However, these errors have had a marginal impact on the results, with magnitudes and direction of associations for adjusted odds ratios much the same after correction. The corrected (italic) and incorrect (bold) odds ratios are presented in the table below to demonstrate the changes in estimates.

The original article can be found online at https://doi.org/10.1007/ s12020-019-02160-z.

$\triangle$ Henrik Falhammar

henrik.falhammar@ki.se

1 Department of Molecular Medicine and Surgery, Karolinska Institutet, Stockholm, Sweden

2 Department of Endocrinology, Metabolism and Diabetes, Karolinska University Hospital, Stockholm, Sweden

3 Department of Laboratory Medicine, Division of Clinical Pharmacology, Karolinska University Hospital Huddinge, Karolinska Institutet, Stockholm, Sweden

4 Department of Clinical Science and Education, Södersjukhuset AB, Karolinska Institutet, Stockholm, Sweden 


\begin{tabular}{|c|c|c|c|c|}
\hline & $\begin{array}{l}\text { Newly initiated } \\
\text { glucose-lowering } \\
\text { medicationCORRECTEDAdj. } \\
\text { OR }(95 \% \text { CI })\end{array}$ & $\begin{array}{l}\text { Newly initiated } \\
\text { glucose-lowering } \\
\text { medicationINCORRECTAdj. } \\
\text { OR }(95 \% \mathrm{CI})\end{array}$ & $\begin{array}{l}\text { Ongoing } \\
\text { glucose-lowering } \\
\text { medication CORRECTEDAdj. } \\
\text { OR }(95 \% \text { CI })\end{array}$ & $\begin{array}{l}\text { Ongoing } \\
\text { glucose-lowering } \\
\text { medication INCORRECTAdj. } \\
\text { OR }(95 \% \mathrm{CI})\end{array}$ \\
\hline Insulins & $0.96(0.57 ; 1.59)$ & $1.17(0.81 ; 1.68)$ & $0.63(0.55 ; 0.72)$ & $0.54(0.48 ; 0.61)$ \\
\hline Metformin & $0.72(0.44 ; 1.16)$ & $0.67(0.46 ; 1.01)$ & $0.86(0.77 ; 0.97)$ & $0.82(0.73 ; 0.91)$ \\
\hline Sulfonylurea & $0.65(0.28 ; 1.38)$ & $0.92(0.56 ; 1.46)$ & $0.90(0.75 ; 1.07)$ & $0.78(0.66 ; 0.92)$ \\
\hline DPP4-inhibitors & $1.00(0.23 ; 3.18)$ & $1.18(0.40 ; 3.07)$ & $0.77(0.44 ; 1.31)$ & $0.72(0.42 ; 1.19)$ \\
\hline GLP1-analogues & $2.26(0.53 ; 8.70)$ & $2.36(0.54 ; 8.90)$ & $0.17(0.04 ; 0.54)$ & $0.17(0.04 ; 0.52)$ \\
\hline Thiazolidinediones & $3.18(0.09 ; 113)$ & $4.69(0.39 ; 58.36)$ & $0.76(0.36 ; 1.50)$ & $0.73(0.38 ; 1.34)$ \\
\hline Meglitinides & $0.16(0.02 ; 0.87)$ & $0.93(0.32 ; 2.53)$ & $0.77(0.49 ; 1.16)$ & $0.72(0.48 ; 1.06)$ \\
\hline $\begin{array}{l}\text { Any glucose- } \\
\text { lowering } \\
\text { medication }\end{array}$ & $0.83(0.52 ; 1.30)$ & $0.87(0.63 ; 1.18)$ & $0.69(0.63 ; 0.75)$ & $0.62(0.57 ; 0.67)$ \\
\hline
\end{tabular}

Publisher's note Springer Nature remains neutral with regard to jurisdictional claims in published maps and institutional affiliations.

Open Access This article is licensed under a Creative Commons Attribution 4.0 International License, which permits use, sharing, adaptation, distribution and reproduction in any medium or format, as long as you give appropriate credit to the original author(s) and the source, provide a link to the Creative Commons license, and indicate if changes were made. The images or other third party material in this article are included in the article's Creative Commons license, unless indicated otherwise in a credit line to the material. If material is not included in the article's Creative Commons license and your intended use is not permitted by statutory regulation or exceeds the permitted use, you will need to obtain permission directly from the copyright holder. To view a copy of this license, visit http://creativecommons. org/licenses/by/4.0/. 